\title{
Krizno komuniciranje u Hrvatskoj 2020.: izvori informacija, povjerenje u institucije i meka moć država
}

\author{
Damir Jugo \\ Edward Bernays Visoka škola, Zagreb, Hrvatska \\ e-mail:damir.jugo@bernays.hr
}

Božo Skoko

Sveučilište u Zagrebu, Fakultet političkih znanosti, Hrvatska

e-mail: bozo.skoko@fpzg.hr

\author{
Mario Petrović \\ Millenium promocija, Zagreb, Hrvatska \\ e-mail: mario.petrovic@mpr.hr
}

SAŽETAK U Hrvatskoj je 2020. godinu potpuno opravdano nazvati kriznom godinom. Osim pandemije bolesti COVID-19, s kojom se suočio cijeli svijet, Hrvatsku je pogodilo više razornih potresa, koji su dodatno intenzivirali osjećaj nesigurnosti i neizvjesnosti među građanima. Stoga je komunikacija izvršne vlasti i ključnih javnih institucija koje su sudjelovale u upravljanju kriznim situacijama cijele godine imala obilježja kriznog komuniciranja.

Rad polazi od pretpostavke da je za učinkovito komuniciranje tijekom krize izuzetno važno povjerenje ugroženih javnosti u izvore iz kojih primaju ključne informacije, ali i povjerenje $\mathrm{u}$ institucije i organizacije koje upravljaju krizom te komuniciraju različite instrukcijske informacije, informacije prilagodbe te reputacijske informacije. Budući da su građani izloženi globalnim komunikacijskim izvorima, zahvaljujući kojima su percipirali i drukčije načine i modele upravljanja posljedicama pandemije diljem Europe i svijeta, mogli su na razini percepcije uspoređivati hrvatske napore s iskustvima i praksama drugih zemalja.

Rad analizira navedena područja kriznog komuniciranja, preferirane izvore informiranja tijekom kriza te povjerenje u institucije i organizacije koje su (bile) uključene u upravljanje kriznim situacijama. Koristeći elemente koncepta meke moći, autori istražuju i kako hrvatski građani percipiraju upravljanje pandemijskom krizom drugih država svijeta, otkrivajući tako njihove priželjkivane modele i uzore, te na perceptivnoj razini uspoređuju ponašanje hrvatskih institucija u krizi s onima drugih europskih i svjetskih država. 
Rezultati provedenog istraživanja mogu upravljačima krizom u Hrvatskoj značajno pomoći u usmjeravanju i planiranju komunikacije te kanaliziranju poruka preferiranim komunikacijskim kanalima kao i pružiti važan uvid u stupanj povjerenja koji građani imaju u hrvatske institucije, ali i one drugih europskih i svjetskih država.

Ključne riječi: kriza, krizno komuniciranje, izvori informacija, povjerenje u institucije, meka moć.

\section{Uvod}

Republika Hrvatska i njezini građani suočili su se u 2020. godini s više različitih kriznih situacija. U ožujku je Svjetska zdravstvena organizacija proglasila pandemiju bolesti COVID-19 za cijeli svijet, a istovremeno je u Hrvatskoj Ministarstvo zdravstva proglasilo epidemiju bolesti COVID-19 za područje čitave Republike Hrvatske (MIZ RH, 2020.). Uz pandemiju odnosno epidemiju, Hrvatske je građane tijekom 2020. godine pogodilo i više razornih potresa, među kojima se ističu onaj u Zagrebu 22. ožujka 2020. magnitude 5,5 po Richteru (PMF, 18. travnja 2020.) te onaj u Petrinji 29. prosinca 2020. godine magnitude 6,2 po Richteru (PMF, 29. siječnja 2021.).

Epidemija i potres potpuno su različite krizne situacije. S jedne strane, bolest COVID-19 svojom je pojavom bila potpuno nepoznata, učinkoviti tretmani liječenja nisu postojali, a svijet se suočio s dotad nezapamćenim mjerama socijalnog distanciranja, koje su zahtijevale potpunu promjenu načina življenja, poslovanja i komuniciranja te u velikoj mjeri utjecale na psihološko, zdravstveno i socijalno stanje ljudi (Suppawittaya i sur., 2020.: 12). Znanstvenici širom svijeta ubrzano su istraživali podrijetlo, sastav, način širenja i različite mutacije virusa te surađivali u brojnim pokušajima razvoja novog cjepiva, u čemu su i uspjeli krajem 2020. godine, kada su u Velikoj Britaniji i cijepljene prve osobe (Wodak, 2021.: 2). S druge strane, potresi s kojima su se suočili hrvatski građani u Zagrebu, Petrinji i okolici izravno su prouzročili ogromne materijalne štete. Šteta nakon zagrebačkog potresa procijenjena je na 11,6 milijardi eura, što čini oko 60 posto godišnjeg državnog proračuna Hrvatske, dok je procijenjena vrijednost ukupne izravne štete prouzročene petrinjskim potresom 5,5 milijardi eura, što je 10,2 posto bruto nacionalnog dohotka Republike Hrvatske (MGIPU, 2. lipnja 2020.).

No unatoč svojim različitostima, krize s kojima su se suočili građani Hrvatske tijekom 2020. godine imale su zajedničko obilježje svake krizne situacije - nesigurnost, za koju Bauman (2006.: 2) objašnjava da uzrokuje pojavu straha kao pojma kojim oni suočeni s kriznom situacijom opisuju neizvjesnost, prijetnju i neznanje kako se s njome suočiti i kako ju zaustaviti. Krizne situacije, u koje se nedvojbeno ubrajaju pandemije te potresi kao elementarne nepogode, neovisno o svojim specifičnostima, uzrocima ili vrstama, karakteriziraju vrlo slična obilježja; one su atipični događaji koji se mogu predvidjeti, ali su ipak neočekivani kad se zaista i dogode, one mogu uzrokovati veliku 
štetu organizacijama i društvu u cjelini, kao i pojedincima koji im pripadaju te prisiljavaju organizacije i društva da komuniciraju s različitim skupinama zbog ograničavanja opasnosti koje one mogu proizvesti, pri čemu upravo kvaliteta komunikacije može poboljšati ili pogoršati situaciju (Jugo, 2017.: 23). Uzimajući u obzir važnost koju komunikacija ima za suočavanje sa svim posljedicama kriznih situacija te polazeći od postavki situacijske krizne teorije komunikacije (Coombs, 2007.: 163), koja naglašava da odabir ispravne strategije, odnosno odgovora u krizi može značajno utjecati na njezin konačni ishod, čini se opravdanim analizirati povjerenje građana zahvaćenih kriznim situacijama u Hrvatskoj tijekom 2020. godine u državne institucije koje su upravljale krizom, ali i usporediti njihovu percepciju hrvatskog modela upravljanja s praksama i modelima drugih država o kojima su mediji ekstenzivno izvještavali.

\section{Kriza, krizno upravljanje i krizno komuniciranje}

Postoje brojne definicije kriznih situacija. One su događaji koji vode rastu rizika, koji mogu potpasti pod snažno medijsko zanimanje ili nadzor vlasti (Fink, 2002.: 15), anomalični događaji koji mogu negativno utjecati na organizacije ili društvo i koji zahtijevaju učinkovitu komunikaciju kako bi se šteta povezana s njima smanjila u što većoj mjeri (Zaremba, 2010.: 20), neplanirani i nepoželjni procesi ograničenog trajanja i mogućnosti utjecaja s ambivalentnim ishodom (Krystek, 1987., prema Tomić, 2008.: 362). Definicije kriza različitih autora međusobno se preklapaju, pa Sellnow i Seeger (2013.: 6) ističu tri primarna obilježja krize koje one najčešće sadržavaju: (1) nepredvidivost i povreda očekivanog, jer dionici krizu dočekaju nepripremljeni, iako joj najčešće prethode znakovi upozorenja, (2) prijetnja koju kriza predstavlja za ciljeve organizacija, živote, imovinu, sigurnost, zdravlje i psihološku stabilnost ljudi te (3) hitna aktivnost, odnosno hitan odgovor pojedinaca, skupina ili organizacije kojima je moguće obuzdati i ograničiti njezine negativne posljedice.

$S$ ciljem što učinkovitije borbe $s$ kriznom situacijom provodi se niz aktivnosti organiziranih $s$ ciljem umanjivanja njezinih negativnih učinaka, koje se nazivaju kriznim upravljanjem (Jugo, 2017.: 25). Fink (2002.: 5) definira krizno upravljanje kao umjetnost uklanjanja rizika i nesigurnosti radi postizanja višeg stupnja kontrole nad vlastitom sudbinom. Uklanjanje rizika ne može spriječiti krizu, ali može umanjiti štetu koju će kriza izazvati (Luecke, 2005.: 17).

Dijalog između organizacije i njezinih javnosti neposredno prije krize, za njezinog trajanja i po njenom završetku naziva se kriznim komuniciranjem (Fearn-Banks, 2011.: 2). Krizno komuniciranje jedno je od vrsta odnosa s javnošću koje može omogućiti uspješno prevladavanje krize te čak ojačati ugled onog tko krizom upravlja (Skoko, 2006.: 90). Sellnow i Seeger (2013.: 13) krizno komuniciranje definiraju kao „kontinuirani proces stvaranja podijeljenog značenja između skupina, zajednica, pojedinca i organizacija, sve radi pripreme, ograničavanja i odgovaranja na rizike i moguće štete“. 


\section{Važnost učinkovitog komuniciranja informacija tijekom krize}

Teorijski okvir ovog rada sastoji se od dva dijela. Prvi počiva na postavkama situacijske krizne teorije komunikacije (Coombs, 2007.: 164), koja naglašava kako organizacije suočene $s$ kriznom situacijom imaju mogućnost izbora strategije, odnosno pristupa kojim će javnosti osigurati odgovarajuće informacije o krizi. Ta teorija dodatno naglašava kako postoje tri faktora koji u kriznoj situaciji mogu utjecati na sam ishod komunikacije, odnosno prenošenje informacija javnosti i dionicima: (1) odgovornost za krizu, odnosno percepcija javnosti koliko je organizacija koja komunicira odgovorna za krizu, (2) povijest krize, odnosno kako je organizacija dotad reagirala u sličnim kriznim situacijama te (3) prethodna reputacija, odnosno način na koji je organizacija dotad postupala i komunicirala s dionicima koji su se našli usred krizne situacije (Coombs i Holladay, 2002.: 183).

Brojne su preporuke autora i praktičara kako komunicirati u krizi. Coombs (2012.: 139) ističe kako postoje tri osnovna obilježja uspješnog i učinkovitog kriznog komuniciranja: brzina, konzistentnost i otvorenost. Oni koji upravljaju kriznom situacijom smatrat će se vjerodostojnijima kada budu dovoljno brzi da upravo oni sami i prvi, prije drugih izvora informacija, obavijeste javnost o postojanju krizne situacije (Arpan i Pompper, 2003.: 291). Konzistentnost kao potreba da se komuniciraju iste poruke također je izuzetno važna, budući da je porukama koje su međusobno usklađene mnogo lakše vjerovati nego onima koje to nisu (Jugo, 2017.: 157). Konačno, otvorenost kao dostupnost medijima i javnosti te spremnost na dijeljenje informacija posebno dolazi do izražaja u dobu kada novi mediji poput društvenih mreža imaju sve veći doseg i utjecaj, pa oni koji upravljaju komunikacijom u krizi trebaju kontinuirano stvarati dojam o vlastitoj dostupnosti te tako ispunjavati očekivanja svojih dionika (Coombs, 2012.: 144). U prilog tezi o važnosti kako se komunicira tijekom krize piše i Zaremba (2010.: 126-129), koji, među ostalim, ističe kako dionici manje pamte samu kriznu situaciju, a više kako je organizacija na nju reagirala te ističe potrebu za konzistentnim i brzim prosljeđivanjem poruka, što će kao posljedicu imati vjerodostojnost organizacije i onih koji u njezino ime upravljaju komunikacijom za vrijeme krize.

Informacije koje organizacija treba komunicirati javnostima zahvaćenim krizom moguće je strukturirati u tri sljedeće kategorije: (1) instrukcijske informacije, koje se usredotočuju na prenošenje uputa kako se zaštititi od mogućih posljedica krize, (2) informacije prilagodbe, koje pomažu dionicima i javnosti da se psihički nose s krizom i stresom koji izazivaju nesigurnost i mogu prouzročiti štetu te (3) upravljanje ugledom i njegov popravak, koji počivaju na pretpostavci da organizacije koje upravljaju krizom moraju voditi računa i o tome kako neutralizirati negativne posljedice za svoj imidž (Coombs, 2012.:146). U kontekstu informacija koje je potrebno komunicirati tijekom krize, Endsley, Wu i Reep (2014.: 162) ističu kako način na koji pripadnici krizom zahvaćene zajednice doživljavaju informacije o kriznim događajima može imati dramatične posljedice za ishod krize, a nekada može izravno utjecati na nečiji ži- 
vot. Važnost vjerodostojnosti izvora informacija o kriznim događajima ističu u svojim istraživanjima i Reich (2011.), Shoemaker i Vos (2009.), McComas i Trumbo (2001.) te Vaagana i sur. (2010.) (prema van Zoonen i van der Meer, 2015.: 372). Upravo iz važnosti izvora informacija tijekom krize proizlaze prva dva istraživačka pitanja ovog rada:

IP1: Koja je razina povjerenja hrvatskih građana u institucije, organizacije, skupine i pojedince kad su u pitanju informacije o pandemiji bolesti COVID-19?

IP2: Koja je razina povjerenja u informacije o pandemiji bolesti COVID-19 objavljene u medijima i postoji li razlika u razini povjerenja ovisno o vrsti medija?

\section{Meka moć država i koncept zemlje podrijetla}

Drugi dio teorijskog okvira rada počiva na konceptu meke moći država i konceptu zemlje podrijetla. Naime, poznato je kako države, kao akteri međunarodnih odnosa na globalnoj političkoj sceni, svoje ciljeve mogu postići na tri načina: prisilom i prijetnjom, plaćanjem ili uvjeravanjem. Dok prva dva načina opisuju tradicionalne odrednice temeljene na ekonomskoj moći, političkom utjecaju i vojnoj sili, tzv. tvrdoj moći, kao protuteža se javlja moć kojom se ciljevi postižu na jedan posve drugačiji način - stjecanjem naklonosti, sposobnošću uvjeravanja i privlačenja. Ta protuteža tradicionalnom shvaćanju moći definirana je konceptom meke moći. Termin „meka moć države“ pripisuje se Josephu S. Nyeu, koji smatra kako država može postići rezultate koje želi u svjetskoj politici zato što je druge države žele slijediti, diviti se njezinim vrijednostima, oponašati njezin primjer, težiti njezinoj razini napretka i otvorenosti (Nye, 2002.: 8). Nye (2002.: 9) smatra kako meku moć ne možemo poistovjetiti isključivo s utjecajem, iako ona predstavlja jedan od izvora utjecaja. Ona je više od uvjeravanja ili pokretanja ljudi snagom argumenata. Autor smatra kako meka moć predstavlja sposobnost zavođenja i privlačenja, a privlačenje često vodi do oponašanja. Ako država uspije svoju moć učiniti legitimnom u očima drugih, njezine želje naići će na manji otpor (Nye, 2002.: 9).

Nye (2004.: 107) smatra kako su ključni izvori moći države - njezina kultura (ovisno o tome koliko je privlačna drugima), političke vrijednosti (kad se sukladno njima država ponaša i kod kuće i u inozemstvu) te njezina vanjska politika (ukoliko ju drugi vide kao legitimnu is moralnim autoritetom).

Prema Van Dykeu i Verčiču (2009.: 828), koji tumače teorijski koncept Jospeha Nyea, izgubi li nacija poštovanje i kredibilitet na međunarodnom planu, to bi moglo dovesti do erozije njezinih temelja, što slabi efikasnost meke moći i čini upotrebu tvrde moći (vojska, gospodarstvo...) vjerojatnijom, a veća upotreba tvrde moći, često percipirane manje etičnom od meke moći, mogla bi dovesti do daljnjeg gubitka kredibiliteta naci- 
je i do povećane nestabilnosti. Dodaju kako literatura o mekoj i tvrdoj moći sugerira i da su te dvije koncepcije povezane te da moraju funkcionirati u međusobnom skladu.

Prema Nyeu (2010.), moć u tradicionalnom političkom okruženju pripadala je državi $s$ jačom vojnom i ekonomskom silom, no u informacijskom dobu prednost u politici imaju države koje su bolji komunikatori.

Nancy Snow (2008.: 4) navodi kako postoje tri dimenzije koje pridonose djelotvornijoj mekoj moći: kultura i ideje koje odgovaraju dominantnim globalnim vrijednostima i normama, pristup višestrukim komunikacijskim kanalima, koji mogu utjecati na način kako su bitne teme i pitanja uokvirena (prikazana) u globalnim medijima i vjerodostojnost zemlje, koja je ojačana njenim unutrašnjim uređenjem i zadovoljstvom građana (političkim vrijednostima) kao i utjecajem na međunarodnoj sceni i odnosima s drugim državama.

Iako je relativno malo država u svijetu koje se mogu natjecati na temelju tvrde moći, ipak je teško pronaći državu koja nije bogata barem nekim oblikom nematerijalne imovine, jer gotovo svaka država na Zemlji posjeduje širok raspon kulturnog, povijesnog, zemljopisnog, ljudskog i intelektualnog kapitala, ali nije imala dovoljno uvjeta, sposobnosti, motivacije ili sreće da ih pretvori u ekonomsko bogatstvo. Upravo za takve države posljednjih se godina na globalnoj pozornici otvara prostor za hvatanje koraka s bogatima. Naime, koncept temeljen isključivo na ekonomskoj, vojnoj i političkoj moći lagano gubi primat i otvara se prostor za brendove koji se ponašaju po drugačijim pravilima, primjerice koji se natječu više u kulturnoj izvrsnosti nego u ekonomskoj snazi (Skoko, 2009.: 98). Zato Anholt (2007.: 113) piše da ljudski kapital zemlje postaje više nego ikad prije ključni faktor u njezinu ekonomskom napretku.

U kontekstu pandemije niz je država koje su pokušale iskoristiti kriznu situaciju te se svojim primjerom u pogledu načina borbe protiv virusa SARS-CoV-2 nametnuti kao globalni uzor u upravljanju krizom (najprije u učinkovitom zatvaranju, pridržavanju pravila, potom u kontroliranom popuštanju mjera, pomaganju gospodarstva, znanstvenim istraživanjima vezanim uz cjepivo, a na koncu učinkovitom opskrbom cjepivom i postizanjem razine procijepljenosti). Države poput Rusije i Kine otvoreno su koristile izvoz i donacije cjepiva kao alat meke moći prema državama Balkana i EUa, Bliskog istoka i Afrike.

Kad je u pitanju razina povjerenja građana u kvalitetu pojedinih cjepiva, tu možemo primijeniti i teorijski koncept zemlje podrijetla.

Koncept ili učinak zemlje podrijetla (engl. country of origin effect), poznat i kao madein fenomen jedan je od najpoznatijih i najistraženijih teorijskih koncepata o učincima imidža zemlje. Bavi se utjecajem imidža zemlje na percepciju njezinih proizvoda od potrošača na inozemnim tržištima. (usp. Allred, 1997.: 12) 
Papadopoulos (1993.: 7) smatra kako je imidž zemalja u njihovoj ulozi podrijetla proizvoda jedan od vanjskih znakova koji može postati dio sveukupnog imidža proizvoda. Pojednostavljeno rečeno, koncept se svodi na tvrdnju kako su potrošači blagonakloniji prema proizvodima iz država s prepoznatljivim i poželjnim imidžom, te su za njih nerijetko spremni platiti i višu cijenu, bez obzira na stvarnu kvalitetu (Skoko, 2009.: 110). Učinak zemlje podrijetla također nam pokazuje kako potrošači određene proizvode ili kategorije proizvoda povezuju s određenim zemljama (primjerice tehniku s Japanom, gastronomiju s Italijom, automobile s Njemačkom, modu s Francuskom...) i na taj su način spremni pozitivnije vrednovati sve brendove unutar te kategorije iz dotične zemlje.

Kotler i Gertner (2005.: 41) tvrde kako se imidž brenda države izravno odražava na njezine proizvode i usluge te sva druga nastojanja na globaliziranom tržištu te ističu kako se proizvodi koji nose oznaku Made in Germany, Made in Switzerland ili Made in Japan smatraju vrlo kvalitetnima, a za to je zaslužna reputacija tih zemalja kao proizvođača i izvoznika koji su u samom svjetskom vrhu.

Iako su teoretičari u početku bili nepovjerljivi prema tom konceptu i ocjenjivali ga previše praktičnim za uključivanje u discipline potrošačkog ponašanja, koje su više teoretske prirode, tijekom devedesetih godina prošlog stoljeća taj je koncept postao jedan od vodećih na području izučavanja utjecaja imidža države, a od tada do danas objavljene su na stotine serioznih studija i istraživanja. Stoga je kroz prizmu tog teorijskog koncepta moguće promatrati i proizvođače cjepiva, odnosno percepciju njihove kvalitete u odnosu na zemlju podrijetla, čemu je posvećen drugi dio istraživanja.

\subsection{Globalni indeks meke moći}

Brand Finance, jedna od vodećih konzultantskih institucija za procjenu vrijednosti brendova, sa sjedištem u Londonu, kreirala je Globalni indeks meke moći, koji od 2020. godine objavljuje ljestvicu država prema snazi njihove meke moći. Rezultat je to opsežnog anketnog (internetskog) istraživanja 60 država iz cijelog svijeta, a u kojem je sudjelovalo više od 55.000 ispitanika u 100 zemalja svijeta (anketni upitnik kreiran je na 42 jezika). U istraživanje je bilo uključeno više od 50 tisuća ispitanika opće javnosti iz gotovo 90 različitih država svijeta, zajedno $s$ više od tisuću stručnjaka iz 87 zemalja koji su percipirani kao mete meke moći (poslovni lideri, tržišni analitičari, političari, akademici, članovi think tankova, novinari te aktivisti nevladinih organizacija). Stajališta opće javnosti iznosila su 75\%, a stručnjaka 25\% finalne ocjene. Riječ je o najvećem istraživanju takve vrste na svijetu. Prvo istraživanje objavljeno je 2020., a drugo 2021. godine.

Brand Finance smatra kako se meka moć države temelji na tri univerzalna mjerila te sedam specifičnih dimenzija (stupova). Univerzalna mjerila su: bliskost - upoznatost 
(ako ljudi znaju više o nekoj zemlji, njezinim talentima, tvrtkama i potencijalima, njezina je moć veća), ugled (kako bi nacija bila privlačna i postala uzor, njezin cjelokupna reputacija mora biti jaka i pozitivna) i utjecaj (percipirana globalna prisutnost i utjecaj koji zemlja ima na druge zemlje, odnosno je li doseg utjecaja lokalan, regionalan ili globalan). Sedam stupova predstavljaju: poslovanje $i$ trgovina (snaga gospodarstva, lakoća poslovanja, brendovi, porezi, trgovina, ulaganja, infrastruktura), vladavina (zakoni, ljudska prava, razina kriminala, sigurnost, ustav, političke elite), međunarodni odnosi (diplomatski odnosi, međunarodne organizacije, sukobi, odluke, međunarodna pomoć, zaštita okoliša), kultura $i$ baština (sport, hrana, likovna umjetnost, književnost, glazba, film, industrija zabave, moda), mediji $i$ komunikacija (tradicionalni mediji, društveni mediji, marketing), obrazovanje i znanost (visoko obrazovanje, znanost, tehnologija) te ljudi i vrijednosti (vrijednosti, karakter, povjerenje). Sve to zajedno čini deset glavnih kategorija, unutar kojih je još 30 povezanih potkategorija (mjera), koje su ispitanici ocjenjivali za svaku od 60 ponuđenih država (Brand Finance Soft Power Index, 2020.).

U istraživanju objavljenom 2021. godine uvršteno je i dodatno mjerilo, koje se odnosi na učinkovitost zemlje u borbi protiv pandemije bolesti COVID-19. Unutar te kategorije mjereni su sljedeći parametri: upravljanje gospodarstvom tijekom krize, dobrobit i zdravlje ljudi te međunarodne aktivnosti. U toj kategoriji poredak država (prema učinkovitosti odgovora na izazove pandemije) izgleda ovako: Novi Zeland, Japan, Švicarska, Njemačka, Kanada, Norveška, Finska, Danska, Južna Koreja, Singapur, Australija, Austrija, Švedska, Nizozemska, Ujedinjeni Arapski Emirati itd. Slovenija je na 21. mjestu, Rusija na 23., Kina na 30., Izrael na 33., Srbija na 43. a Hrvatska na 64., dok su Sjedinjene Američke Države na 105. mjestu.

U izvješću stoji kako su brzi odgovor na pandemiju i jasnoća komuniciranja u rješavanju krize od vlade Novog Zelanda prepoznati kao uzoran primjer u globalnim medijima i među građanima drugih zemalja, a samim time i kao meka moć te države, dok je odgovor američkog predsjednika Trumpa na krizu izazvao kontroverze i kod kuće i u inozemstvu (Brand Finance Soft Power Index, 2021.: 44). Spomenuti indeks govori nam o važnosti te problematike, a njegove ćemo rezultate usporediti $s$ istraživanjem $u$ Hrvatskoj.

Iz navedenih koncepata proizlaze i druga dva istraživačka pitanja ovog rada:

IP3: Kako građani u Hrvatskoj percipiraju uspješnost borbe hrvatskih institucija s pandemijom bolesti COVID-19 i njezinim posljedicama te koje države smatraju uzornima u tome?

IP4: Kakva je percepcija učinkovitosti cjepiva za COVID-19 s obzirom na zemlju njihova podrijetla među hrvatskim građanima? 


\section{Metodologija}

S ciljem iznalaženja odgovora na postavljena istraživačka pitanja provedeno je anketno istraživanje metodom prikupljanja podataka CATI na nacionalno reprezentativnom uzorku u cijeloj Republici Hrvatskoj u drugoj polovici veljače 2021. godine. U istraživanju je sudjelovalo ukupno 630 ispitanika $(\mathrm{N}=630)$, pri čemu je potrebno napomenuti da je uzorak ispitanika ponderiran s obzirom opću, punoljetnu populaciju RH, kako bi bio komparabilan s karakteristikama opće populacije. Tako je 51,3 posto ispitanika bilo ženskog spola, njih 28,8 posto u dobnoj skupini od 18 do 34 godine, 27,4 posto od 35 do 49 godina, 26 posto od 50 do 64 godine te 17,8 posto starije od 65 godina. Više od polovice ispitanika ( 56,6 posto) imalo je završenu srednju školu, njih 25,8 posto samo osnovnu školu, a 17,7 posto završen studij. Više od polovice ispitanika (51,1 posto) bilo je zaposleno, 27,1 posto u mirovini, 13,8 posto nezaposleno, a 7,9 posto bili su studenti ili učenici.

Sudionici istraživanja odgovarali su na četiri zatvorena pitanja s ponuđenim odgovorima. U prvom pitanju ispitanici su ocjenjivali razinu povjerenja koje imaju u informacije o pandemiji koje su im komunicirale različite institucije, organizacije, skupine i pojedinci. Povjerenje je mjereno skalama Likertovog tipa od 1 do 5 , pri čemu je 1 značilo nisku razinu povjerenja, a 5 visoku razinu povjerenja. Drugo pitanje ispitivalo je razinu povjerenja ispitanika u različite vrste medija, također Likertovom skalom kao u prvom pitanju. U trećem su pitanju ispitanici zamoljeni da između 12 ponuđenih država istaknu onu za koju smatraju da se najučinkovitije nosila s pandemijom bolesti COVID-19, dok su u četvrtom pitanju sudionici zamoljeni da između pet ponuđenih država istaknu onu za koju smatraju da je razvila najučinkovitije cjepivo za bolest COVID-19.

\section{Rezultati istraživanja}

\section{IP1.: Koja je razina povjerenja hrvatskih građana u institucije, organizacije, sku- pine i pojedince kad su u pitanju informacije o pandemiji bolesti COVID-19?}

Prvo istraživačko pitanje nastojalo je utvrditi razinu povjerenja koje su sudionici istraživanja imali u informacije koje su tijekom pandemije bolesti COVID-19 primali od različitih organizacija, skupina i pojedinaca. $S$ obzirom na potrebu ponderiranja uzorka, prije statističke analize podataka bilo je potrebno provjeriti zadovoljavaju li podaci uvjet sfericiteta. Pretpostavka sfericiteta odnosi se na uvjet jednakosti varijanci između svih parova varijabli. U slučaju da taj uvjet nije zadovoljen, potrebno je koristiti korigiranu mjeru testa značajnosti, odnosno Greenhouse-Geisserovu korekciju (Girden, 1992.: 19). 
Za testiranje sfericiteta korišten je Mauchlyjev test sfericiteta (Salkind, 2010.: 776), koji je pokazao kako postoje statistički značajne razlike u varijancama na skalama (W $=0,232, \mathrm{P}<0,001)$. Zbog nezadovoljavanja uvjeta sfericiteta, u prikazu rezultata testiranja razlika koristit će se Greenhouse-Geisserova korekcija (Girden, 1992.: 19). Dobiveni F-omjer testa značajnosti razlika između prosječnih ocjena povjerenja u informacije o pandemiji bolesti COVID-19 iznosi $\mathrm{F}=204,190$ i statistički je značajan $(\mathrm{p}<0,001)$, što ukazuje na postojanje statistički značajnih razlika u ocjenama povjerenja u institucije. Budući da F-omjer ukazuje na to da postoji statistički značajna razlika između prosječnih ocjena povjerenja, ali ne i na to između kojih parova tvrdnji postoji razlika, učinjen je post hoc test razlika između parova tvrdnji.

Slika 1.

Prosječne ocjene povjerenja u institucije (ocjene $1-5$ ).

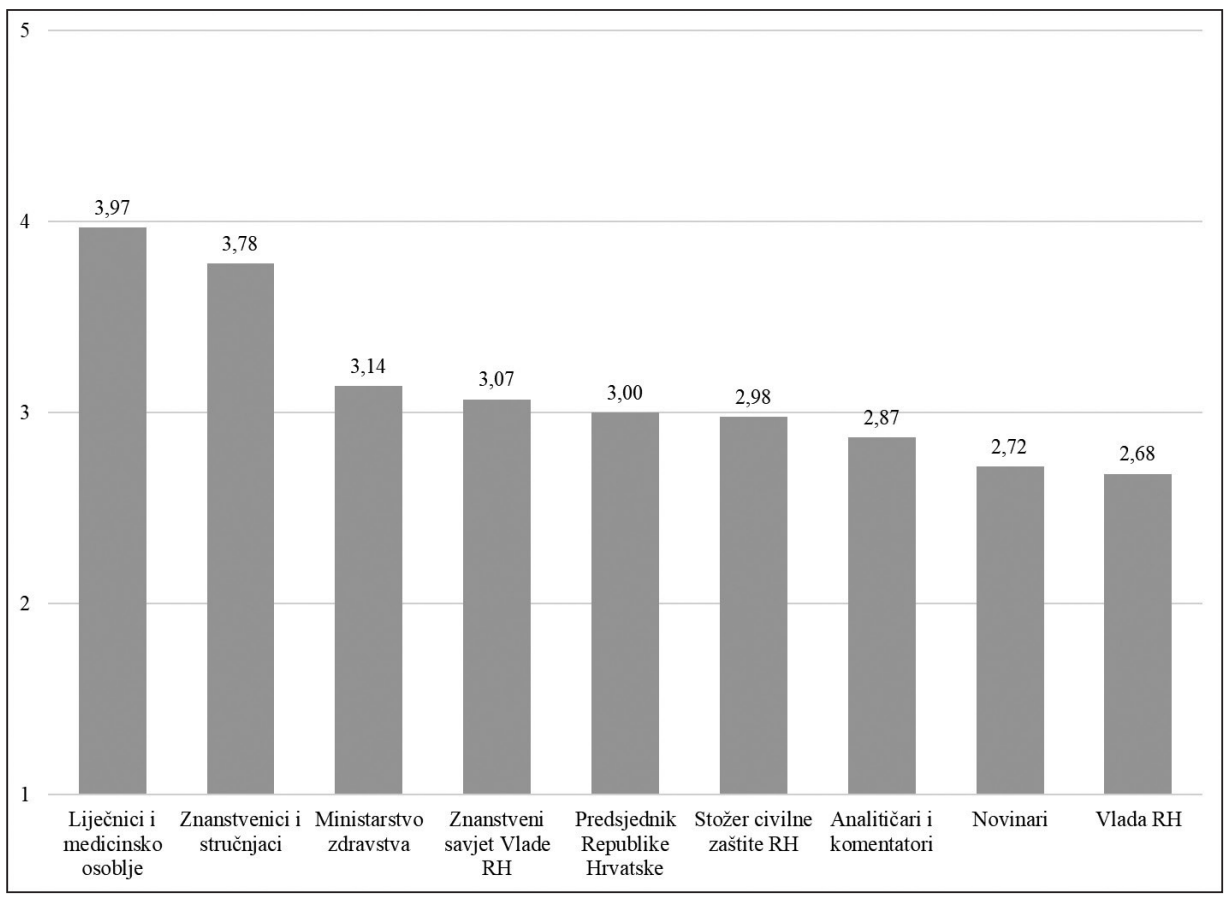

Prema provedenoj analizi statističke značajnosti razlika u prosječnim ocjenama između pojedinih parova institucija, organizacija, skupina i pojedinaca vidljivo je kako između prosječnih ocjena povjerenja gotovo svih parova postoje statistički značajne razlike. Izuzetak su ocjene Stožera civilne zaštite i Predsjednika RH, između kojih nema statistički značajne razlike (prosječne ocjene iznose 2,98 i 3,00). Također, između prosječnih ocjena Znanstvenog savjeta Vlade i Predsjednika RH nije utvrđena statistički značajna razlika (prosječne ocjene 3,07 i 3,00). 
Kad je u pitanju povjerenje u pojedine izvore informacija, uvjerljivo su najlošije ocijenjeni Vlada RH i novinari, skupine između kojih nije utvrđeno postojanje statistički značajne razlike (prosječne ocjene 2,68 i 2,72). S druge strane, ispitanici su kao izvore u koje imaju najviše povjerenja istaknuli liječnike i medicinsko osoblje, a odmah potom i znanstvenike i stručnjake, što sugerira kako su tijekom pandemije građani tražili prije svega provjerene informacije među skupinama stručnjaka, a tek potom u različitim državnim institucijama. Zanimljivo je istaknuti razliku u stupnju povjerenja u primjerice Ministarstvo zdravstva $(3,14)$ i Vladu RH $(2,68)$, iako je za pretpostaviti da su tijekom pandemije komunicirali identične ili barem usklađene informacije.

Iz analiziranih podataka primjetno je kako osobe ženskog spola imaju ukupno nešto veću razinu povjerenja u izvore informacija nego osobe muškog spola $(3,2$ naspram 3,0). Državnim institucijama i izvršnoj vlasti (Stožer civilne zaštite, Vlada, Ministarstvo, Predsjednik) u većoj mjeri vjeruju ispitanici iz starijih dobnih skupina, ispitanici sa završenom osnovnom školom te umirovljenici, studenti i učenici. Najviši stupanj iskazanog povjerenja prema liječnicima i medicinskom osoblju zabilježen je među učenicima i studentima $(4,4)$, umirovljenicima $(4,3)$, ispitanicima sa završenom osnovnom školom $(4,3)$ te onima iz najstarije dobne skupine ( $65-74$ godine). $S$ druge strane, najniži stupanj povjerenja prema Vladi RH iskazali su ispitanici iz dobne skupine 35 - 49 godina starosti te ispitanici sa završenom srednjom školom. Zanimljivo je primijetiti i kako su ispitanici iz dobne skupine 18 - 34 godine najnižu razinu povjerenja $(2,3)$ iskazali prema novinarima kao izvoru informacija o pandemiji.

\section{IP2.: Koja je razina povjerenja u informacije o pandemiji bolesti COVID-19 objavljene u medijima i postoji li razlika u razini povjerenja ovisno o vrsti medija?}

Drugo istraživačko pitanje ispitivalo je razinu povjerenja u medije, ali i razliku među medijima kad je u pitanju povjerenje građana. Statistička značajnost razlika testirana je analizom varijance za ponovljena mjerenja, a kao i kod IP1 provjereno je zadovoljavaju li podaci uvjet sfericiteta. Za testiranje sfericiteta korišten je Mauchlyjev test sfericiteta (Salkind, 2010.: 776), koji je pokazao kako postoje statistički značajne razlike u varijancama na skalama ( $\mathrm{W}=0,402, \mathrm{P}<0,001)$. Zbog nezadovoljavanja uvjeta sfericiteta u prikazu rezultata testiranja razlika koristit će se Greenhouse-Geisserova korekcija (Girden, 1992.: 19). Dobiveni F-omjer testa značajnosti razlika između prosječnih ocjena povjerenja u informacije o pandemiji bolesti COVID-19 objavljene $u$ različitim medijima iznosi $\mathrm{F}=107,407$ i statistički je značajan $(\mathrm{p}<0,001)$. Budući da F-omjer ukazuje na to da postoji statistički značajna razlika između prosječnih ocjena povjerenja u informacije, ali ne i na to između kojih parova medija postoji razlika, učinjen je post hoc test razlika između parova. 
Slika 2.

Prosječne ocjene povjerenja u medije (ocjene 1 - 5).

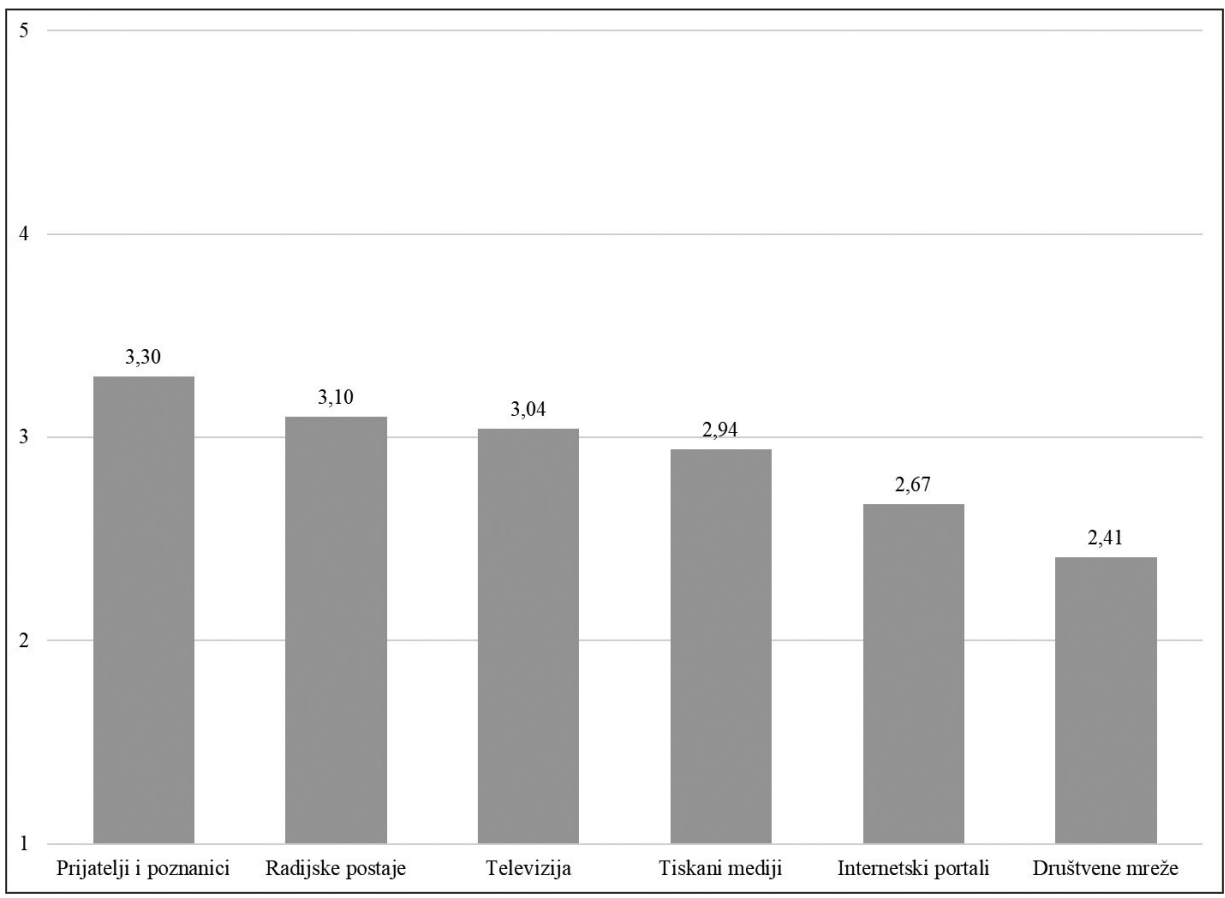

Prema analiziranim razlikama prosječnih ocjena povjerenja u izvore informacija o pandemiji bolesti COVID-19, gotovo su sve razlike između prosječnih ocjena ispitivanih izvora informacija statistički značajne. Izuzetak su prosječne ocjene povjerenja u informacije objavljene u programu radijskih i televizijskih postaja, između kojih ne postoji statistički značajna razlika u prosječnoj ocjeni povjerenja.

Tako su prijatelji i poznanici nedvojbeno statistički značajno više ocijenjeni od svih ostalih izvora informacija, te su izvor informacija o pandemiji u koji su građani imali najviše povjerenja. Slijede radijske i televizijske postaje, između kojih nema statistički značajnih razlika u razini povjerenja te tiskani mediji, s nešto nižom razinom povjerenja. Značajno nižu razinu povjerenja kad su u pitanju informacije o pandemiji bolesti COVID-19 ispitanici su iskazali prema internetskim portalima, a uvjerljivo najmanje povjerenja imali su u informacije objavljene, odnosno dostupne na društvenim mrežama.

Kad su u pitanju demografske karakteristike ispitanika, nisu utvrđene značajne razlike među njima kad je u pitanju spol. Nešto višu razinu povjerenja u odnosu na ostale ispitanike u televiziju, radio i tiskane medije iskazali su stariji ispitanici te oni $s$ nižom razinom obrazovanja. Ispitanici sa završenim studijem imali su nešto više nego ostali ispitanici povjerenja u informacije objavljene na internetskim portalima $(2,8$ 
naspram 2,6), kao i ispitanici iz dobne skupine $35-49$ godina starosti $(2,8)$. Ukupno su najvišu razinu povjerenja u medije kao izvore informacija imali ispitanici iz redova učenika-studenata $(3,2)$ te ispitanici sa završenom osnovnom školom $(3,1)$, dok su najskeptičniji bili zaposleni ispitanici $(2,8)$ te najmlađi ispitanici iz dobne skupine $18-34$ godine $(2,8)$.

\section{IP3: Kako građani u Hrvatskoj percipiraju uspješnost borbe hrvatskih institucija $s$ pandemijom bolesti COVID-19 i njezinim posljedicama te koje države smatraju uzornima u tome?}

U trećem istraživačkom pitanju istraživali smo percepciju uspješnosti borbe hrvatskih institucija s pandemijom bolesti COVID-19 i njezinim posljedicama, u komparaciji s drugim državama svijeta. Nastojali smo otkriti modele uspješnog upravljanja krizom iz perspektive hrvatskih građana te istodobno utvrditi razinu zadovoljstva hrvatskim modelom u odnosu na modele drugih država. Pošavši od hipoteze kako ne postoji statistički značajna razlika u postocima odabira država s obzirom na percepciju borbe protiv pandemije bolesti COVID-19, a budući da se radi o postocima odabira u jednoj varijabli, razlike između postotaka testirane su Hi-kvadrat testom, u kojem su komparirane stvarne distribucije postotaka s uniformnom distribucijom postotaka. Kao i u prethodnim analizama, i ovdje je uzorak ispitanika ponderiran s obzirom na opću, punoljetnu populaciju Hrvatske.

Dobivena vrijednost Hi-kvadrat testa iznosi $\chi^{2}=566,24 \mathrm{uz} p<0,001$, što jasno potvrđuje očite razlike u distribuciji ukupne distribucije postotaka odgovora. Zato su dodatno testirane razlike u postocima pojedinih država. Prema dobivenoj distribuciji odgovora države su grupirane u dvije skupine prema postotku odgovora. Države s višim postocima odgovora nego ostale su: Hrvatska, Švedska, Njemačka i Novi Zeland, kod kojih se postoci kreću od 14,5 do 17,9\%.

Hi-kvadrat test distribucija postotaka odgovora između navedene četiri države iznosi $\chi^{2}=0,705 \mathrm{uz} p=0,876$, te nije statistički značajan. Prema tome rezultatu razlika $\mathrm{u}$ postocima odgovora između Hrvatske, Švedske, Njemačke i Novog Zelanda nije statistički značajna, te prema dobivenim podacima nije opravdano razlikovati te četiri države prema percepciji učinkovitosti nošenja s pandemijom bolesti COVID-19.

Nadalje, sve ostale države su analizirane na isti način kao i četiri države s visokim postocima odgovora. Hi-kvadrat testom testiralo se razlikuju li se postoci odgovora od distribucije u kojoj sve države imaju isti postotak odgovora. Treba napomenuti kako je iz analize izuzet odgovor "Neka druga“. Dobivena vrijednost Hi-kvadrata iznosi $\chi^{2}=$ 43,840 uz $\mathrm{p}<0,001$, što ukazuje na statistički značajne razlike u postocima odgovora za preostale države. Među tim državama relativno je najviši postotak odgovora vezan 
uz Bosnu i Hercegovinu, te je sljedeća analiza isključivala Bosnu i Hercegovinu. Analiza distribucije postotaka odgovora koja je isključivala četiri države $s$ visokim postocima odgovora te Bosnu i Hercegovinu, koja od preostalih država ima najviši postotak odgovora, dala je vrijednost Hi-kvadrata $\chi^{2}=7,075$ uz $p=0,316$. Dakle, izuzme li se iz preostalih država Bosna i Hercegovina, analiza ne pokazuje statističku značajnost razlika u distribucijama postotaka odgovora.

Slika 3.

Distribucije postotaka odgovora na pitanje o državama koje su se najuspješnije nosile s pandemijom bolesti COVID-19

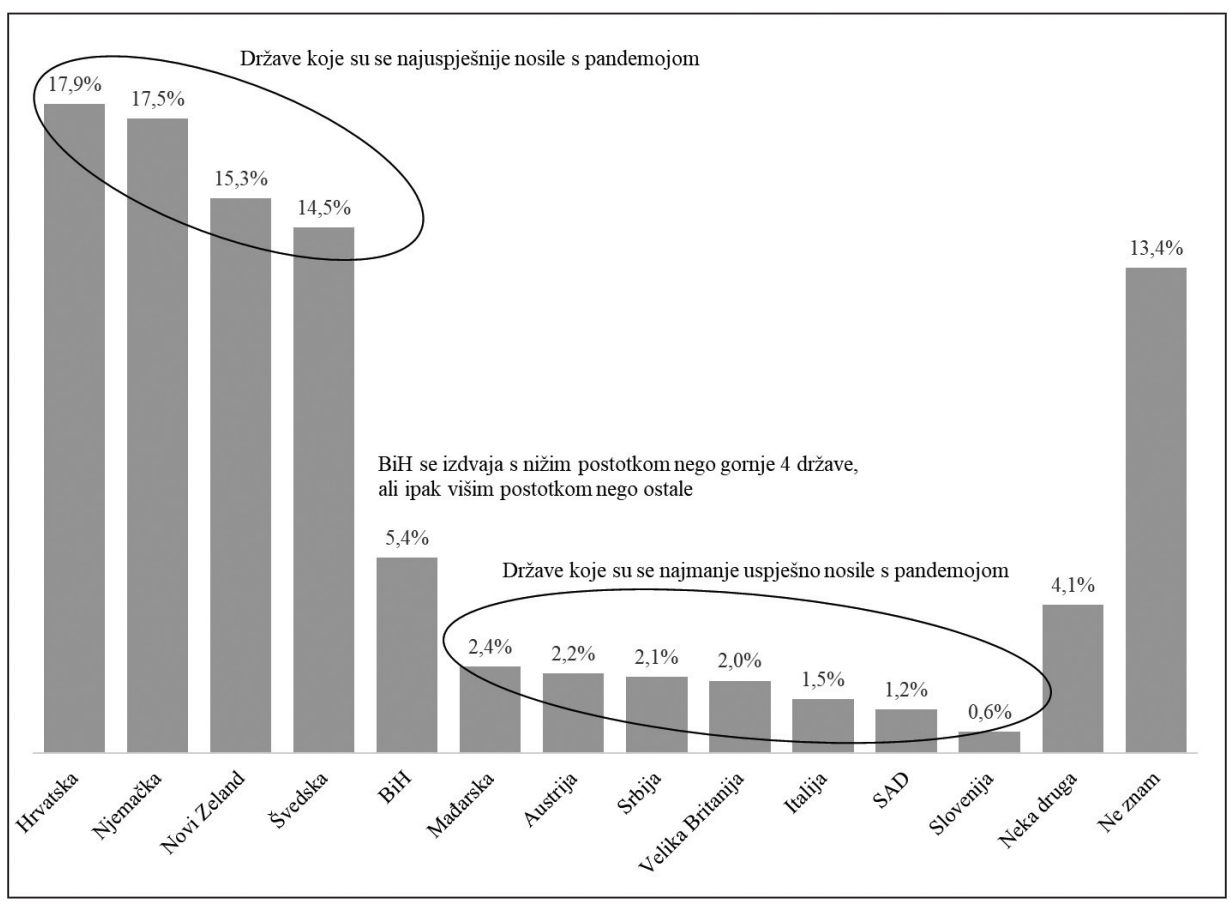

$\mathrm{Na}$ temelju distribucije postotaka i provedene analize razlika Hi-kvadrat testom može se zaključiti kako se države grupiraju u tri skupine. Hrvatska, Švedska, Njemačka i Novi Zeland percipiraju se kao zemlje koje su se najuspješnije (odnosno podjednako uspješno) nosile s pandemijom, zatim slijedi Bosna i Hercegovina te u trećoj skupini država sve ostale države koje su se podjednako (ne)uspješno nosile s pandemijom.

Prema tome, može se zaključiti kako ipak postoji razlika u percepciji država s obzirom na uspješnost nošenja s pandemijom bolesti COVID-19. Pritom je zanimljiva činjenica kako su kao uspješni modeli borbe protiv bolesti COVID-19 percipirane zemlje koje su imale potpuno različite pristupe u borbi s pandemijom. Istraživanje također otkriva visoku razinu povjerenja ispitanika u učinkovitost Hrvatske kad je u pitanju borba protiv pandemije i njezinih posljedica. A zanimljiva je pozicija Bosne i 
Hercegovine, koja je imala očitih problema u borbi protiv pandemije, ali je cijelo vrijeme zadržala prilično liberalne mjere, što je očito bilo važno hrvatskim ispitanicima. Stariji ispitanici te oni s nižom stručnom spremom u većoj su mjeri birali Hrvatsku kao najuspješniju državu u borbi s pandemijom, dok su mlađi ispitanici te ispitanici $s$ višim obrazovanjem i većim primanjima značajnije birali Novi Zeland te Švedsku kao uspješne modele.

\section{IP4: Kakva je percepcija učinkovitosti cjepiva za COVID-19 s obzirom na zemlju njihova podrijetla među hrvatskim građanima?}

Četvrto istraživačko pitanje fokusirano je na percepciju učinkovitosti cjepiva za COVID-19 s obzirom na zemlju podrijetla. Kao i kod prethodne analize, kako se radi o postocima odabira u jednoj varijabli, razlike između postotaka testirane su Hi-kvadrat testom, u kojem su komparirane stvarne distribucije postotaka s uniformnom distribucijom postotaka. I ovdje je uzorak ispitanika uravnotežen (ponderiran) s obzirom na opću, punoljetnu populaciju Hrvatske kako bi uzorak bio komparabilan s karakteristikama opće populacije.

Hi-kvadrat test razlika u distribucijama postotaka odgovora na pitanje o državi podrijetla cjepiva iznosi $\chi^{2}=83,880$ uz $\mathrm{p}<0,001$. Prema tome nalazu evidentno je kako između postotaka postoje statistički značajne razlike.

U sljedećem koraku u analizu su uzete Njemačka i Rusija kao dvije države s najvišim postotkom odgovora. Vrijednost Hi-kvadrata usporedbe postotaka za Njemačku i Rusiju iznosi $\chi^{2}=0,127 \mathrm{uz} p=0,768$, što nije statistički značajno. Dakle postoci odgovora za Njemačku i Rusiju ne razlikuju se statistički značajno. Pridoda li se Njemačkoj i Rusiji SAD, kao država s trećim najvišim postotkom odgovora, vrijednost Hi-kvadrat testa iznosi $\chi^{2}=8,000 \mathrm{uz} p=0,018$, što je statistički značajna razlika. Iz toga i iz prethodne usporedbe Njemačke i Rusije slijedi kako se SAD u statistički značajno nižem postotku percipira kao država s najučinkovitijim razvijenim cjepivom. U sljedećem koraku izvedena je Hi-kvadrat analiza razlika SAD-a i Velike Britanije, kao države $s$ nešto nižim postotkom nego SAD. Vrijednost Hi-kvadrat testa usporedbe postotaka za SAD i Veliku Britaniju iznosi $\chi^{2}=2,630$ uz $p=0,116$, što ne predstavlja statističku značajnost. Može se, dakle, zaključiti kako se SAD i Velika Britanija percipiraju podjednako. I na kraju je SAD-u i Velikoj Britaniji dodana i Kina te su analizirane razlike između te tri države. Dobivena vrijednost Hi-kvadrat testa iznosi $\chi^{2}=35,429$ uz $p<$ 0,001 , dakle razlika u distribucijama postotaka odgovora statistički je značajna između SAD-a, Velike Britanije i Kine. 
Slika 4.

Distribucije postotaka odgovora na pitanje o državama koje su razvile najučinkovitije cjepivo za COVID-19

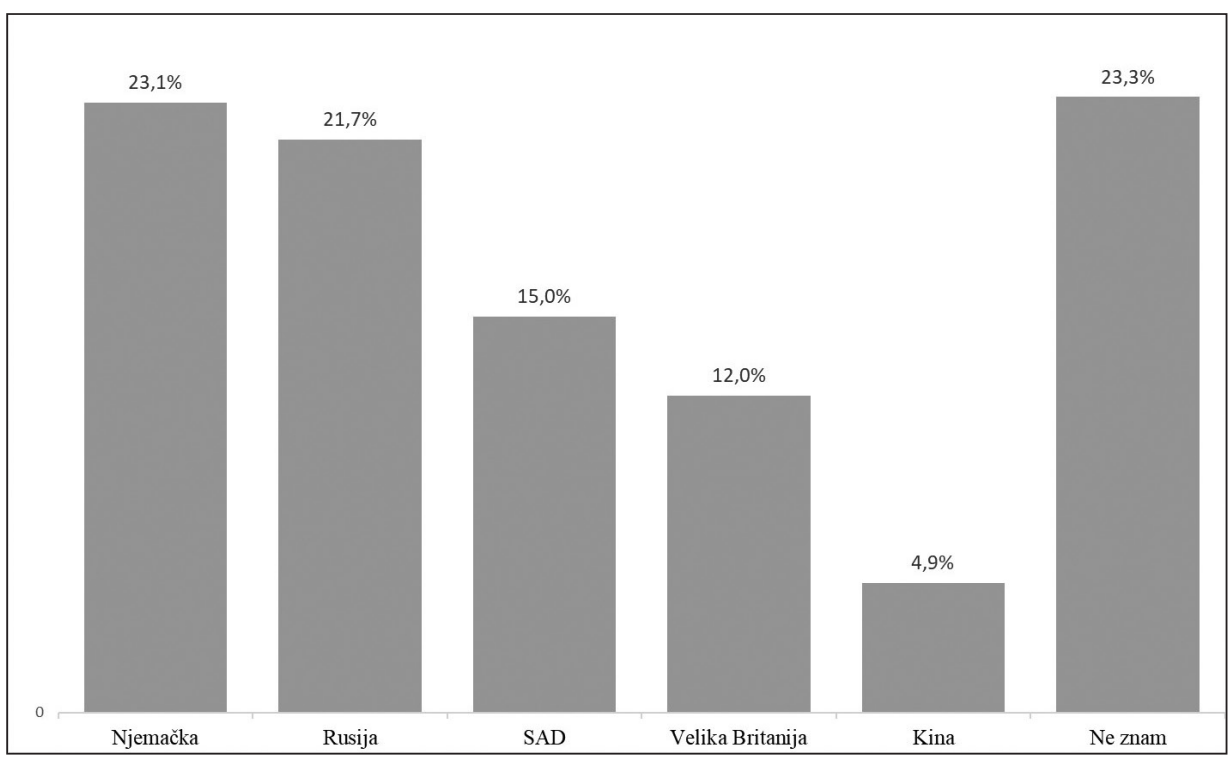

Prema nalazima Hi-kvadrat testova moguće je zaključiti kako se države prema percepciji učinkovitosti razvijenog cjepiva grupiraju u tri skupine. U skupini zemalja $s$ najvišim postocima nalaze se Njemačka i Rusija, u drugoj skupini s nižim postocima nalaze se SAD i Velika Britanija te na kraju Kina s najnižim postotkom percepcije učinkovitosti cjepiva. Zanimljivo je kako je Njemačka kao zemlja podrijetla percipirana izrazito pozitivno iako je Pfizer američka korporacija. Moguća su dva povoda - cjepivo je razvijeno u suradnji s njemačkim BioNTechom, a Njemačka je kao zemlja podrijetla inače percipirana pozitivno u Hrvatskoj (usp. Skoko, 2003.: 315). Zanimljiv je nalaz vezan uz Rusiju kao zemlju podrijetla cjepiva Sputnik, budući da je Rusija rijetko u Hrvatskoj percipirana kao zemlja s poželjnim imidžom, a njezini se proizvodi ne povezuju s kvalitetom. Zahvaljujući takvoj pozitivnoj percepciji cjepiva (iza čega očito stoji povjerenje i u ruska znanstvena istraživanja te tradiciju zdravstva) nema dvojbe kako Rusija može koristiti cjepivo kao alat meke moći na ovim prostorima. Žene su u većoj mjeri sklonije njemačkom cjepivu, dok su muškarci u nešto većoj mjeri skloniji ruskom cjepivu. Ispitanici s osnovnom školom nešto bolje percipiraju cjepivo njemačke proizvodnje (te posebno dobne skupine od 18 do 34 i od 50 do 64), dok ispitanici $s$ fakultetskim obrazovanjem, zaposleni i boljestojeći ispitanici bolje percipiraju rusko cjepivo. Povjerenje u američko i britansko cjepivo u većoj mjeri imaju umirovljenici. Istodobno umirovljenici u odnosu na ostale skupine ispitanika imaju najmanju razinu povjerenja u rusko cjepivo. 


\section{Rasprava i zaključak}

U svakoj kriznoj situaciji komunikacija igra značajnu ulogu, a povjerenje u institucije koje upravljaju krizom neophodno je za učinkovitu provedbu potrebnih mjera u sanaciji krize i njezinih posljedica. Zahvaljujući učinkovitoj kriznoj komunikaciji, pri čemu su najvažniji brzina, konzistentnost i otvorenost (Coombs, 2012.), raste razina povjerenja u pojedine izvore, odnosno institucije, dok oni subjekti koji nisu komunicirali pravovremeno, dovoljno predano, transparentno is uvažavanjem sugovornika gube na kredibilitetu.

Prema provedenom istraživanju o razini povjerenja u hrvatske institucije, organizacije, skupine i pojedince koji su bili komunikatori tijekom krizne 2020. godine u Hrvatskoj, pokazalo se kako su liječnici i medicinsko osoblje te znanstvenici i stručnjaci bili najkredibilniji izvori informacija o pandemiji među hrvatskim građanima. Istodobno se najmanje vjerovalo novinarima i Vladi. Građani su pozitivno percipirali i resorno Ministarstvo zdravstva te Znanstveni savjet Vlade kao kredibilne izvore. Rezultate možemo dovesti u vezu i s ranijim istraživanjem (Grbeša, 2020.), koje je pokazalo kako je medijsko izvještavanje o ključnim akterima tijekom prva tri mjeseca krize bilo uvjerljivo pozitivno te kako su ključni ljudi koji su upravljali krizom prihvatili strategije uvjeravanja tipične za komuniciranje u pandemijama, ponajprije uporabu poruka straha, vojnih metafora i poruka koje inzistiraju na „zajedništvu“ $\mathrm{i}$ „pandemijskom sramoćenju“. Grbeša (2020.) zaključuje kako su pozitivna medijska prezentacija komunikatora i strategije uvjeravanja koje su koristili vjerojatno potaknuli ljude da vjeruju njihovim odlukama i pristanu na restriktivne mjere, koje su suspendirale njihove slobode i gotovo preko noći promijenile njihove životne navike. $U$ tom kontekstu zanimljivo je vidjeti nalaze istraživanja o izrazitom povjerenju u komunikatore sa znanstvenim, odnosno stručnim referencama i kredibilitetom nasuprot Vladi, koja se percipira kao političko tijelo, pa joj se i manje vjeruje.

Kad je u pitanju razina povjerenja u informacije objavljene u medijima i drugim komunikacijskim kanalima, rezultati analize pokazuju kako je najviša razina povjerenja u informacije dobivene od prijatelja i poznanika, a potom slijede tradicionalni elektronički mediji - radio i televizija. Najniža je razina povjerenja u općeprisutne društvene medije. Ti rezultati jasno govore o važnoj ulozi tradicionalnih medija u informiranju građana tijekom krize, odnosno važnosti kredibilnih i provjerenih izvora, ali i iskoraku hrvatskih medija u učinkovitom praćenju kriznih situacija te sadržajnoj prilagodbi novonastaloj situaciji. Posebno valja istaknuti svojevrsnu renesansu radija, čija slušanost i utjecaj rastu u kriznim situacijama (usp. Kedžo, 2015.; Mučalo, 2010.) Kao što je vidljivo, društvene mreže, koje su inače u Hrvatskoj najčešći izvor informacija, nisu imale presudnu ulogu tijekom krize, a nasuprot anonimnim komunikatorima na internetu informacije su se provjeravale i komentirale s obitelji, prijateljima i poznanicima, koji su se pokazali najvažnijim „filterom“ u razumijevanju situacije. 
Pored nacionalnih i lokalnih medija u Hrvatskoj, hrvatski građani izloženi su i globalnim komunikacijskim izvorima, zahvaljujući kojima su također percipirali i drukčije načine i modele upravljanja posljedicama pandemije diljem Europe i svijeta, te su mogli na razini percepcije uspoređivati hrvatske napore $s$ iskustvima i praksama drugih zemalja.

Iz analize rezultata vidljivo je kako je Hrvatska prema percepciji učinkovitosti ocijenjena pri vrhu, zajedno s Njemačkom, Novim Zelandom i Švedskom. Valjalo bi podrobnije istražiti razloge pozitivne percepcije hrvatskih mjera, ali za pretpostaviti je kako je u pitanju kombinacija učinkovitosti mjera s liberalnijim pristupom „zatvaranju " u odnosu na ostatak Europe. To možemo iščitati u pozitivnom stajalištu prema švedskom modelu, ali i pozitivnoj percepciji Bosne i Hercegovine. Novi je Zeland medijski bio prezentiran kao jedan od najučinkovitijih modela na svijetu, pa nema dvojbe kako je to također utjecalo na percepciju. Hrvatski su građani prilično orijentirani prema Njemačkoj, kao zemlji podrijetla, ali i modelu upravljanja, pa nema dvojbe kako se ta percepcija odrazila i na pozitivnu percepciju njemačkih mjera u ovom istraživanju, iako su bile daleko strože od onih u Hrvatskoj.

Ovaj dio istraživanja dijelom se podudara s globalnim istraživanjem (Brand Finance Soft Power Index, 2021.) o snazi meke moći pojedinih država kad je u pitanju suočavanje s pandemijom. Naime, i u Hrvatskoj su pozitivno percipirani Novi Zeland i Njemačka, koji su na vrhu spomenute ljestvice. Raskorak je donekle kod Švedske, čiji je model daleko pozitivnije percipiran u Hrvatskoj nego na globalnoj razini, te kod percepcije učinkovitosti Hrvatske i Srbije u upravljanju krizom uzrokovanom koronavirusom. Dok Brand Finance daleko bolje pozicionira Srbiju - 43. mjesto (zbog učinkovitosti u nabavci cjepiva) nego Hrvatsku - 64. mjesto, hrvatski su građani iznimno zadovoljni načinom suočavanja s krizom hrvatskih institucija, dok je od Srbije bolje percipirana čak i Bosna i Hercegovina kad su u pitanju načini upravljanja krizom (podsjetimo, $\mathrm{BiH}$ je imala ozbiljne probleme s nabavkom cjepiva, kriminalne radnje oko nabave respiratora, ali prilično liberalne mjere oko zatvaranja ugostiteljskih objekata). Za pretpostaviti je kako su učinkovitost u nabavi cjepiva u Srbiji u hrvatskom javnom mnijenju zasjenile medijske informacije o uvođenju policijskog sata te sporadičnim nekontroliranim povećanjima broja oboljelih i umrlih.

Kad je u pitanju percepcija učinkovitosti cjepiva za COVID-19 s obzirom na zemlju njihova podrijetla među hrvatskim građanima, najpozitivnije su percipirane Njemačka i Rusija kao zemlje podrijetla najučinkovitijeg cjepiva, dok je Kina percipirana kao država s najmanje učinkovitim cjepivima. Odnos prema Njemačkoj kao zemlji podrijetla možemo dovesti u vezu s prethodnim tumačenjem i pozitivnim odnosom Hrvata prema toj zemlji, ali i činjenicom da su (u Hrvatskoj) najpopularnije cjepivo Pfizer patentirali njemački znanstvenici. Kad je Rusija u pitanju, neophodno bi bilo nastaviti istraživanja koja bi otkrila dublje razloge takvog izbora. No, jedna od pretpostavki jest 
povjerenje u ruske znanstvenike i istraživače te sustav kvalitete i kontrole u zdravstvu. U tom bi kontekstu bilo zanimljivo istražiti i odnos prema drugim ruskim kategorijama proizvoda kako bi se napravila valjana usporedba te dao doprinos razumijevanju koncepta zemlje podrijetla. Naime, poznato je kako iz pojedine države mogu biti pozitivno percipirane tek pojedine kategorije proizvoda, dok druge države koje uživaju veći ugled daju dodanu vrijednost svim proizvodima. U svakom slučaju, pozitivno percipirane države u kontekstu borbe protiv pandemije, kao i njihova cjepiva, svoje iskustvo, znanje, modele upravljanja i proizvode mogu iskoristiti kao svojevrsnu meku moć u jačanju političkih i gospodarskih odnosa s drugim državama.

S druge strane, komunikatori tijekom krize u Hrvatskoj, žele li učinkovitije upravljati kriznim situacijama, nedvojbeno će morati u većoj mjeri koristiti kredibilitet i autoritet znanstvenika i stručnjaka, a manje politike. Također će se u kriznim situacijama morati oslanjati više na tradicionalne medije poput televizije, radija i tiska nego na suvremene medijske kanale poput društvenih mreža.

\section{Literatura}

1. Allred, T. A. (1997). Measuring country image to explain product attitudes, doktorska disertacija. Oklahoma State University.

2. Anholt, S. (2007). Competitive Identity, The New Brand Management for Nations, Cities and Regions. New York: Palgrave Macmillan.

3. Arpan, L. M. and Pompper, D. (2003). Stormy weather: Testing "stealing thunder" as a crisis communication strategy to improve communication flow between organizations and journalists. Public Relations Review, 29 (3): 291-308.

4. Bauman, Z. (2006). Liquid Fear. Cambridge: Polity Press.

5. Brand Finance (2020). Global Soft Power Index 2020. https://brandirectory. com/globalsoftpower/download/brand-finance-global-soft-power-index-2020. pdf. (Pregledano 12. prosinca 2020.)

6. Brand Finance (2020). Global Soft Powers Index 2020. https://brandirectory. com/globalsoftpower/dashboard. (Pregledano 17. prosinca 2020.)

7. Brand Finance (2020). Nation Brands 2020 - The annual report on the most valuable and strongest nation brands, November 2020. https://brandirectory.com/ download-report/brand-finance-nation-brands-2020-preview.pdf. (Pregledano 18. prosinca 2020.)

8. Brand Finance (2021). Global Soft Power Index 2020. https://brandirectory. com/globalsoftpower/download/brand-finance-global-soft-power-index-2021. pdf. (Pregledano 12. travnja 2021.)

9. Brand Finance Whitepaper (2020). Soft Power: Why it Matters to Governments, People \& Brands. July 2020. brand-finance-whitepaper-2020-soft-power-whyit-matters-to-governments-people-and-brands.pdf. (brandirectory.com) (Pregledano 15. prosinca 2020.) 
10. Coombs, W. T. (2007). Protecting organization reputations during a crisis: The development and application of situa- tional crisis communication theory. Corporate Reputation Review, 10 (3): 163-176.

11. Coombs, W. T. (2012). Ongoing Crisis Communications. Los Angeles: Sage Publications.

12. Coombs, W. T. and Holladay, S. J. (2002). Helping crisis managers protect reputational assets initial tests of the situational crisis communication theory. Management Communication Quarterly, 16 (2): 165-186.

13. Fearn Banks, K. (2011). Crisis Communications: A Casebook Approach. New York: Routlege.

14. Fink, S. (2002). Crisis Management: Planning for the Inevitable. Cincinnati: Authors Guild.

15. Girden, E. R. (1992). ANOVA repeated measures. Newbury Park: SAGE Publications.

16. Grbeša, M. (2020). Communication COVID-19 pandemic: media coverage of the headquarters and the use of persuasion strategies in Croatia. Anali Hrvatskog politološkog društva, 17 (1): 57-78.

17. Jugo, D. (2017). Menadžment kriznog komuniciranja. Zagreb: Školska knjiga i Edward Bernays Visoka škola.

18. Kedžo, Z. (2015). Povjerenje u medije i krizno komuniciranje: lokalni radio u izvanrednoj situaciji, doktorska disertacija. Osijek: Sveučilište Josipa Jurja Strossmayera.

19. Kotler, P. and Gertner, D. (2005). Country as brand, product and beyond: a place marketing and brand management perspective, in: Morgan, N.; Pritchard A. and Pride, R. (Eds.). Destination Branding: Creating the Unique Destination Proposition. Oxford: Elsevier Butterworth-Heinemann.

20. Luecke, R. (2005). Upravljanje kriznim situacijama. Zagreb: Harvard Business Essentials i Zgombić i partneri.

21. Ministarstvo graditeljstva i prostornog uređenja Republike Hrvatske. https:// mgipu.gov.hr/o-ministarstvu-15/djelokrug/graditeljstvo-98/obnova-zgradaostecenih-potresom-na-podrucju-sisacko-moslavacke-zupanije-karlovacke-zupanije-i-zagrebacke-zupanije/11384. (Pregledano 2. svibnja 2021.)

22. Ministarstvo zdravstva Republike Hrvatske. https://zdravstvo.gov.hr/ UserDocsImages/2020\%20CORONAVIRUS/ODLUKA\%20O\%20 PROGLAŠENJU\%20EPIDEMIJE\%20BOLESTI\%20COVID-19.pdf. (Pregledano 21. svibnja 2021.).

23. Mučalo, M. (2010). Radio - medij 20. stoljeća. Zagreb: AGM.

24. Nye, S. J. (2002). Paradox of American Power. Oxford University Press.

25. Nye, S. J. (2004). Soft Power: The Means to Success in World Politics. New York: Public Affairs.

26. Nye, S. J. (2010). Nova javna diplomacija. Project Syndicate. http://www.banka.hr/hrvatska/joseph-s-nye-jr-nova-javna-diplomacija. (Pregledano 26. veljače 2010.) 
27. Papadopoulos, N. (1993). What Product and Country Image Are and Are Not, in: Papadopoulos, N. and Heslop, L. A. (Eds.). Product-Country Images: Impact and Role in Interantional Marketing. New York, London, Norwood: International Business Press, 3-38.

28. Piwat, S.; Pakara, Y. and Pratchayapong Y. (2020). Effects of social distancing, self-quarantine and self-isolation during the COVID-19 pandemic on people's well-being, and how to cope with it. International Journal of Science and Healthcare Research, 13 (5) / Issue: 2 (April-June 2020).

29. Salkind, Neil (Ed.) (2010). Encyclopaedia of Research Design, Vol. 1. Sage Publications.

30. Seizmološki odsjek, Prirodoslovno matematički fakultet Sveučilišta u Zagrebu (18. travnja 2020). O Zagrebačkom potresu. https://www.pmf.unizg.hr/geof/seizmoloska sluzba/o zagrebackom potresu 2020. (Pregledano 20. svibnja 2020.)

31. Seizmološki odsjek, Prirodoslovno matematički fakultet Sveučilišta u Zagrebu (29. siječnja 2021). Potresi kod Petrinje. https://www.pmf.unizg.hr/geof/seizmoloska_sluzba/potresi_kod_petrinje. (Pregledano 2. svibnja 2021.)

32. Sellnow, T. and Seeger, M. (2013). Theorizing Crisis Communication. Oxford: Wiley - Blackwell.

33. Skoko, B. (2006). Priručnik za razumijevanje odnosa s javnošću. Zagreb: Millenium promocija.

34. Skoko, B. (2003). Hrvatska - identitet, image, promocija. Zagreb: Školska knjiga.

35. Skoko, B. (2009). Država kao brend. Zagreb: Matica hrvatska.

36. Snow, N. (2009). Rethinking Public Diplomacy, in: Snow, N. and Taylor, P. (Eds.). Routledge Handbook of Public Diplomacy. New York and London: Routledge.

37. Tomić, Z. (2008). Odnosi sjavnošću. Teorija i praksa. Zagreb - Sarajevo: Synopsis.

38. Tristan, E.; Yu W. and James R. (2014). The source of the story: Evaluating the credibility of crisis information sources, in: Shih, P. C.; Plotnick, L.; Pfaff, M. S.; Hiltz, S. R. (Eds.). ISCRAM 2014 Conference Proceedings - 11th International Conference on Information Systems for Crisis Response and Management (pp. 160-164). University Park, PA: The Pennsylvania State University.

39. Van Dyke, M. A. and Verčič, D. (2009). Public Relations, Public Diplomacy and Strategic Communication: An International Model of Conceptual Convergence, in: Sriramesh, K. and Verčič, D. (Eds.). The Global Public Relations Handbook. Routledge.

40. van Zoonen, W. and van der Meer, T. (2015). The importance of source and credibility perceptions in times of crisis: crisis communication in a socially mediated era. Journal of Public Relations Research, 27 (5): 371-388.

41. Wodak, R. (2021). Crisis communication and crisis management during COVID-19. Global Discourse, vol 00, no 00: 1-20. DOI: 10.1332/204378921X161 00431230102.

42. Zaremba, A. (2010). Crisis Communication: Theory and Practice. New York: M. E. Sharpe. 
Izvorni znanstveni rad

\title{
Crisis Communication in Croatia in 2020: Sources of Information, Trust in Institutions and the Soft Power of Countries
}

Damir Jugo

Edward Bernays University College, Zagreb, Croatia

e-mail:damir.jugo@bernays.hr

Božo Skoko

University of Zagreb, Faculty of Political Science, Croatia

e-mail: bozo.skoko@fpzg.hr

Mario Petrović

Millenium promocija, Zagreb, Croatia

e-mail:mario.petrovic@mpr.hr

\begin{abstract}
In Croatia, it is completely justified to brand 2020 as a crisis year. Besides the COVID-19 pandemic that affected the entire world, Croatia faced a number of strong earthquakes, which further increased the feelings of insecurity and uncertainty among its citizens. Therefore, the communication of the Government, as well as the key public institution handling the crisis, can undoubtedly be seen as, dominantly, crisis communication.
\end{abstract}

This paper is based on the assumption that efficient crisis communication needs to establish the trust of the endangered publics into the sources that provide them with key information about the crisis, as well as the trust into the institutions and organizations that manage the crisis and communicate different information. Considering the fact that citizens are exposed to various global sources of information, which enabled them to perceive different ways and models of handling the pandemic throughout Europe and the world, they were able to differentiate and compare Croatian efforts to tackle the pandemic with those of different countries.

This paper analyzes the stated fields of crisis communication; preferred sources of information during crises, as well as confidence in institutions and organizations that were involved in handling the crisis situations. The authors use elements of the soft power concept to analyze how Croatian citizens perceive the management of the pandemic in other countries around the world, revealing their models and role models, and comparing the behavior of Croatian institutions during the crisis with those of other European countries and countries around the world.

The results of the conducted research can help individuals and organizations in Croatia that handle crisis situations to direct and plan communication activities, as well as to channel messages to preferred channels, and to provide valuable insight into the level of confidence that Croatian citizens have in Croatian institutions and those of other countries in Europe and around the world.

Key words: crisis, crisis communication, sources of information, trust in institutions, soft power. 